\title{
Compensatory Water Consumption of Broilers Submitted to Water Restriction from 1 to 21 Days of Age
}

- Author(s)
Viola $\mathrm{TH}^{1}$
Ribeiro $\mathrm{AML}^{2}$
Penz Jr. AM ${ }^{3}$
1 Graduate student, Animal Science, UFRGS
2 Professor, scholarship granted by CNPq
3 UFRGS, Departamento de Zootecnia,
Professor

Mail Address

Andréa Machado Leal Ribeiro

UFRGS

Av. Bento Gonçalves, 7712

91.540-000. Porto Alegre, RS, Brasil

E-mail: aribeiro@ufrgs.br

\section{Keywords}

Broilers, compensatory water consumption, water restriction.

\section{ABSTRACT}

A hundred and fifty male Ross 308 broilers were submitted to water restriction (WR) in different levels (0 to $40 \%$ ) until 21 days of age. The birds received water ad libitum from 22 to 28 days of age and the compensatory consumption of water (CConW) was calculated as the difference in water intake between birds submitted and not submitted to WR. All WR groups showed a compensatory consumption of water, mainly during the first days of the ad libitum period. The water intake in such groups decreased as the birds adapted to the new condition. Higher water intake was observed in birds with 30 and 40\% WR than in birds with $10 \%$ WR. Furthermore, chickens showed an unusual drinking and feeding behavior during the restriction period.

\section{INTRODUCTION}

Water is an essential nutrient to every live animal and has been reported as the most important nutrient for growth and development (Counotte, 2003). Increments in water consumption in broilers are associated with age (Leeson et al., 1995).

The restriction of water consumption also decreases feed intake (Brooks, 1994; Larbier \& Leclercq, 1994). If water is supplied ad libitum, the birds develop a very characteristic feed intake behavior and eat during short periods in a day. On the other hand, this behavior may vary according to water availability and management (Macari, 1995). In broilers submitted to feed restriction, water consumption peaks when feed is supplied (Leeson \& Summers, 2000), because water intake is highly related to feed intake (Lesson \& Summers, 2000; Lott et al., 2003). Any factor influencing feed intake will also affect water consumption and vice-versa (Macari, 1995).

\section{MATERIAL AND METHODS}

An experiment using a hundred and fifty one-day-old male Ross 308 broilers was performed in batteries, during 28 days. The birds were distributed into five treatments with three replicates and five animals per replicate. In the first 21 days, the birds were submitted to different water restriction levels as shown in Table 1. Baby chick-type drinkers supplied water once a day, approximately at 12:00 AM and for two hours in the restricted groups. Water was provided ad libitum from 22 to 28 days of age.

The daily water consumption during the ad libitum period (22 to 28 days) was estimated in relation to a control group comprised of six replicates, each containing 10 chicks with initial weight similar to that of the chicks submitted to water restriction. The control group was placed in the cages two days before the beginning of the experiment. 
The daily water consumption of this group was used as a reference to estimate the water intake in the restricted groups.

\begin{tabular}{|c|c|c|}
\hline \multirow[t]{2}{*}{ Treatment } & \multicolumn{2}{|c|}{ Water restriction levels (\%) } \\
\hline & 1 to 21 days & 22 to 28 days \\
\hline 1 & 0 & 0 \\
\hline 2 & 10 & 0 \\
\hline 3 & 20 & 0 \\
\hline 4 & 30 & 0 \\
\hline 5 & 40 & 0 \\
\hline
\end{tabular}

All chicks were fed ad libitum with a diet containing $22 \%$ crude protein, $3100 \mathrm{kcal} / \mathrm{kg}$ AME, $1.26 \%$ Lys, $0.94 \%$ Met-Cys, $1.0 \% \mathrm{Ca}$ and $0.5 \%$ available P. Chicks were raised with 24 -hour light scheme in a room with temperature adjustment performed according to the ROSS 308 manual. Water quality was in agreement with the standards for animal consumption.

Estimation of water intake rate during the experimental period (standard intake) was carried-out using a regression analysis between water consumption in water-restricted birds and age (variable $\mathrm{X})$. Compensatory consumption in the period from 22 to 28 days of age was calculated as the difference in water intake between the groups previously submitted to water restriction and the control group (Ribeiro et al., 2001).

A randomized block design was used with five treatments and three replicates of five chicks per replicate. The blocks were arranged based on initial body weight, so that chicks were divided into three groups: light, medium and heavy weight. Statistical analysis was done using the LSmeans test from GLM module and regression analysis using Statistic Analysis System (SAS, 2001).

\section{RESULTS AND DISCUSSION}

During the water-restriction period (1 to 21 days), the birds were allowed to drink water for a period of 2 hours, independently of the restriction level to which they were assigned. They drank until the physical capacity of the crop was achieved and thus the crop was visually distended and full. After drinking, the chicks would eat feed and regurgitation of water and feed was frequently observed, probably because there was no available space in the crop. These observations in water-restricted birds are in accordance to Brooks (1994) who also reported water intake to the maximum capacity immediately after it had been supplied.
When water was supplied ad libitum (after 22 days of age), bird behavior was similar to that seen in the restricted groups, i.e., there was a marked water intake if the crop capacity was not limiting. This behavior changed slowly with time.

The standard water intake was calculated according to the following equation based on the ad libitum consumption of water:

\section{$W \mathrm{I}=-1.44+10,277 \mathrm{X}$,}

where $\mathbf{X}=$ age (days), and

\section{WI $=$ water intake $(\mathrm{mL})$}

Compensatory consumption of water (CConW) from 22 to 28 days in the different water restriction treatments is presented in Table 2. CConW was similar to all treatments, despite the level of restriction from 1 to 21 days. As the birds adapted to the water supply, there was a decrease in CConW. This observation is in accordance to Macari (1995), who stated that the standard drinking behavior may vary due to changes in water availability.

\begin{tabular}{|c|c|c|c|c|}
\hline \multicolumn{5}{|c|}{$\begin{array}{l}\text { Table } 2 \text { - Compensatory water intake: increase in water intake } \\
(\mathrm{mL} / \text { bird) in restricted birds compared to birds without water } \\
\text { restriction. }\end{array}$} \\
\hline \multirow{2}{*}{$\begin{array}{c}\text { Age } \\
\text { (days) }\end{array}$} & \multicolumn{4}{|c|}{ Restriction (\%) } \\
\hline & 40 & 30 & 20 & 10 \\
\hline \multicolumn{5}{|c|}{ Increase in water intake (mL/bird) } \\
\hline 22 & $218 a$ & $205 a$ & $196 a$ & $213 a$ \\
\hline 23 & $137 \mathrm{a}$ & $137 \mathrm{a}$ & $113 a$ & $85 a$ \\
\hline 24 & $107 \mathrm{a}$ & $116 a$ & $102 a b$ & $39 b$ \\
\hline 25 & $98 \mathrm{a}$ & $89 a$ & $76 a$ & $34 a$ \\
\hline 26 & $67 \mathrm{a}$ & $111 \mathrm{a}$ & 56 a & 59 a \\
\hline 27 & $83 a$ & $58 \mathrm{a}$ & $50 \mathrm{a}$ & $34 \mathrm{a}$ \\
\hline 28 & $21 a$ & $24 a$ & 32 a & $-18 a$ \\
\hline
\end{tabular}

Means followed by different letters in the same row are statistically different by LSmeans test.

The low CConW at day 28 indicates that the previously restricted broilers tended to normalize the water intake after one week when water was provided ad libitum. A linear regression equation was obtained when CCOnW was expressed as a function of age, as follows:

\section{CConW= $768-27 X$, where $\mathrm{X}=$ age (days)}

and $(\mathrm{mL})$ 
Table 3 shows the weekly average of CConW (22 to 28 days) according to the previous restriction levels. Broilers submitted to restrictions of 20 to $40 \%$ had similar compensatory water consumption. Broilers with 30 and $40 \%$ restrictions showed higher compensatory water consumption than those submitted to a $10 \%$ water restriction.

Table 3 - Mean compensatory water consumption from 22 to 28 days: increase in water intake $(\mathrm{mL} / \mathrm{bird})$ in restricted compared to non-restricted birds according to the different levels of water restriction until 21 days.

\begin{tabular}{|c|c|}
\hline Level of restriction $(\%)^{1}$ & Mean CCOnW (mL/bird) \\
\hline 10 & $63 \pm 11^{2} a$ \\
\hline 20 & $88 \pm 10 a b$ \\
\hline 30 & $105 \pm 10 b c$ \\
\hline 40 & $104 \pm 10 b c$ \\
\hline
\end{tabular}

1 - Compared to chickens supplied water ad libitum. 2 - Mean \pm Standard Error. Means followed by different letters are statistically different by LSmeans test $(p<0.02)$

In conclusion, broilers submitted to water restriction show a compensatory water consumption after it is supplied ad libitum. Water restriction leads to changes in drinking and feeding behavior of chickens.

\section{REFERENCES}

Brooks PH. Water: forgotten nutrient and novel delivery system. In: 10 ${ }^{\text {th }}$ Alltech's Annual Ssymposium; 1994; Nicholasville. Proceedings... Nicholasville: Alltech Technical Publication; 1994. p.211-234.

Counotte G. Avicultura profesional: conocer la calidad del água de bebida. Doetinchem: Reed Business Information; 2003. p.20-22.

Larbier M, Leclercq B. Nutrition and feeding of poultry: intake of food and water. Nottingham: Nottingham University Press; 1994. p.7-14

Leeson S, Diaz GJ, Summers JD. Poultry metabolic disorders and mycotoxins: water imbalance. Guelph: University Books; 1995. p.94111.

Leeson S. Summers JDV. Broiler and breeder production: nutrition and feeding. Guelph: University Books; 2000. p.136-217.

Lott BD, Dozier, WA, Simmons JD, Roush WB. Water flow rates in commercial broiler houses. In: International Poultry Scientific Forum; 2003; Atlanta. Summary... Atlanta: CAB; 2003. p.1-14.

Macari M. Metabolismo hídrico da poedeira comercial. In: V Simpósio Técnico de Produção de Ovos; 1995; Jaboticabal. Resumos... Jaboticabal: APA; 1995. p.109-131.
Ribeiro AML, Penz Jr. AM, Teeter RG. Effects of 2-hydroxy-4(methylthio) butanoic acid and DL-methionine on broiler performance and compensatory growth after exposure to two different environmental temperatures. Journal of Applied Poultry Research 2001; 10:419-26.

SAS statistic analysis system. Painless Windows, a handbook for SAS users. $2^{\text {nd }}$ ed. Guelph: Jodie Gilmore; 2001. 61 p. 